Acta pharmacol. toxicol., 3, 165 (1947). - 14. Delbrück, A., F. Hartmann und R. Schneider, Med. Klin. 58, 376 (1963). 15. Junge-Hülsing, G., pers. Mitt. - 16. Asboe-Hansen, G., Physiol. Rev. 38, 446 (1958). - 17. Dorfman, A. und S. SChILler, Recent Progr. Hormone Res. 14, 427 (1958). - 18. Beierwaltes, W. H. und A. J. Bollet, J. Clin. Invest. 38, 945 (1959). 19. Gabrilooe, J. L. und A. W. Ludwig, J. Clin. Endocr.,
Springfield 17, 925 (1957). - 20. BuDdeCkE, E., J. Atherosclerosis Res., Amsterdam 2, 32 (1962). - 21. Randerath, E. und P. B. Diezel, Morphologische Pathologie der extrarenalen Angiopathie bei Diabetes mellitus. Vcrh. III Kongr. Intern. Diabetiker Federation, S. 54, Georg Thieme Verlag, Stuttgart (1959). - 22. Hilz, H., C. Erich und D. Glaubrrt, Klin. VVschr. 41, 332 (1963).
Dozent Dr. A. Delbrück 3 Hannover, Podbielskistr. 380

\title{
The Identification and Determination of Barbiturates in Serum
}

\author{
From the Clinical Chemical Laboratory (Head: H.J. Peters) St. Canisius Hospital, Nijmegen, The Netherlands
}

(Eingegangen am 3. März 1966)

\begin{abstract}
The identification of barbiturates is based on the difference in the distribution coefficients of various barbiturates between chloroform and each of two aqueous alkaline solutions and, furthermore, on differences in the shapes of the absorption spectra for the enol forms of various barbiturates.

The identification and quantitative determination is performed by extracting the serum containing a barbituratc, at $\mathrm{pH} 7.4$ with 50 times its volume of chloroform. Part of the chloroform layer is extracted with dilute $\mathrm{NaOH}$ and the absorption of the extract at 230, 240 and $250 \mathrm{~m} \mu$ is measured at $\mathrm{pH} 10$ and pH 2. Another portion of the chloroform layer is extracted with $\mathrm{Na}_{2} \mathrm{HPO}_{4}$ ( $\mathrm{pH}$ 8.9). The typc of barbiturate present is determined from the difference in absorption at $240 \mathrm{~m} \mu$ of this extract at $\mathrm{pH} 8.9$ and $\mathrm{pH} 2$, together with the previous absorption differences at 240 and $250 \mathrm{~m} \mu$.

The concentration of the barbiturate in serum is calculated from the difference in absorption at $240 \mathrm{~m} \mu$ of solutions at $\mathrm{pH} 10$ and $\mathrm{pH} 2$, using a reference curve for barbital. The value found in this way is multiplied by the appropiate barbiturate factor to give the correct concentration.

The confirmation of barbiturate poisoning is a qualitative as well as a quantitative problem. Before the onset of toxic symptoms, the blood levels of the long-acting barbiturates, such as phenobarbital (luminal) and barbital (veronal), are much higher than those of the short-acting ones, such as hexabarbital ( $\mathrm{N}$-methylcyclohexenyl methyl barbital = evipan). Barbiturates with medium action, such as butobarbital (soneryl), pentobarbital (nembutal) and allobarbital (dial) also show intermediate blood levels.
\end{abstract}

Die Auftrennung von Barbituraten beruht auf der Verschiedenheit der Verteilungskoeffizienten verschiedener Barbiturate zwischen Chloroform und zwei alkalisch-wäßrigen Lösungen, sowie auf den Unterschieden in der Form der Absorptionsspektren für die Enolformen verschiedener Barbiturate.

Die Identifizierung und quantitative Bestimmung wird durch Extraktion des Barbiturat enthaltenden Serums bei $\mathrm{pH}$ 7,4 mit dem 50fachen Volumen Chloroform der Ausgangsserummenge vorgenommen. Ein Teil der Chloroformschicht wird mit verdünnter $\mathrm{NaOH}$ ausgezogen und die Absorption des Extralstes bei 230,240 und $250 \mathrm{~m} \mu$ bei $\mathrm{pH} 10$ und pH 2 gemessen. Ein zweiter Tcil der Chloroformschicht wird mit $\mathrm{Na}_{2} \mathrm{HPO}_{4}$ (pH 8,9) extrahiert. Der anwesende Barbiturattyp wird aus der Differenz in der Absorption dieses Extraktes bei $240 \mathrm{~m} \mu$ bei pH 8,9 und $\mathrm{pH} 2,0$ - zusammen mit den obengenann:en Absorptionsdifferenzen bei 240 und $250 \mathrm{~m} \mu$ - berechnet.

Die Konzentration des Barbiturates im Serum wird aus der Absorptionsdifferenz bei $240 \mathrm{~m} \mu$ der Lösungen bei pH 10 und pH 2 berechnet, wobei eine Bezugskurve für Barbitursäure verwendet wird. Der auf diese Weise gefundene Wert wird mit dem passenden Barbituratfaktor multipliziert und ergibt so die korrekte Konzentration.

SUNSHINE (1) reviewed the correlation between the concentrations of different barbiturates in blood and the established clinical condition. - Comatosis may appear at a blood concentration of $65 \mathrm{mg} / \mathrm{l}$ for a long-acting barbiturate, $45 \mathrm{mg} / \mathrm{l}$ for an intermediate=acting and $25 \mathrm{mg} / \mathrm{l}$ for a short-acting one. - To determine the seriousness of a barbiturate poisoning in a comatose state, it is - in addition to the determination of its concentration in serum - important to know, which barbiturate is present or to which group (long, medium, or short acting) it belongs. Generally, when the patient is not comatose, there will be little necessity to know which barbiturate was taken. Therefore, the identi- fication of barbiturates in most cases will only be necessary if their concentrations in the serum are relatively high.

Several spectrophotometric methods for the quantitative determination and identification of barbiturates are described in the literature (2-8). Identification methods for barbiturates are described by Stevenson (2), HellDORF (5) and Goldbaum (4). VAN HaERingen (3) gave a review and a critical examination of several of these methods. For quantitative determination it appeared that the extraction of acidified serum with a large excess of chloroform and determination of the absorption at $240 \mathrm{~m} \mu$ in a buffer solution of $\mathrm{pH} 10$ and at $\mathrm{pH} 2$ gave 
the most satisfactory results. The method according to Goldiaum (4) gives an indication of the type of barbiturate, but does not identify it specifically.

\section{Method}

Barbiturates can exist in two tautomeric forms, viz, the enol-form and the keto-form, depending on the $\mathrm{pH}$ of the solution. The absorption maximum for barbiturates in weakly alkaline solutions ( $\mathrm{pH} 8.9$ and $\mathrm{pH} 10$ ) is caused by the enol-form and appears at approximately $240 \mathrm{~m} \mu$, with slight variations for the various barbiturates. In acid solutions $(\mathrm{pH} 2)$ the barbiturates exist in the keto-form and show no absorption at $240 \mathrm{~m} \mu$. It must be supposed that the physical properties of a barbiturate, as well as the formation of its enol-or ketoform, at any given $\mathrm{pH}$, are influenced by its substituents. Indeed, DYBING (7) reported that the distribution coefficients of various barbiturates between chloroform and an aqueous solution showed large differences at the same alkaline $\mathrm{pH}$. $\mathrm{He}$ also indicated that the distribution coefficients for one barbiturate between chloroform and aquous solutions of different alkalinities may differ considerably.

The findings of DyBing are confirmed by our investigations. The identification of barbiturates, according to the method described below, is based on the difference in distribution coefficients of the various barbiturates between chloroform and two aqueous alkaline solutions and furthermore on the difference of the absorption curves for the enolforms of the various barbiturates.

Three sera, each containing $200 \mathrm{mg}$ of a different barbiturate, were submitted to the identification and determination procedures described below. The sera were extracted with chloroform. One part of each solution was extracted with an aqueous solution, $\mathrm{pH}$ 8.9. The other part was extracted with $0.1 \mathrm{~N} \mathrm{NaOH}$ to extract the maximum quantity of barbiturate. This alkaline solution was adjusted to $\mathrm{pH} 10$ with boric acid to ensure that the barbiturates were present in the mono-enol form (7). Absorption difference curves between the aqueous solution of $\mathrm{pH} 10$ and $\mathrm{pH} 2$, as well as those of $\mathrm{pH} 8.9$ and $\mathrm{pH} 2$, for wavelengths between 225 and $260 \mathrm{~m} \mu$, are shown in figure 1.

Figure 1 shows that the absorption differences at $240 \mathrm{~m} \mu$ between $\mathrm{pH} 8.9$ and $\mathrm{pH} 2$ and those between $\mathrm{pH} 10$ and $\mathrm{pH} 2$ show ratios that are quite different for each of the barbiturates, although their initial weight concentrations in serum are equal. The different ratios are explained by the different distribution coefficients of the barbiturates between the chloroform and the alkaline solutions. The identification of a barbiturate can be achieved on this

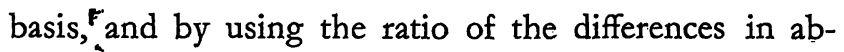
sorption at 240 and $250 \mathrm{~m} \mu$ with solutions of $\mathrm{pH} 10$ and $\mathrm{pH}$ 2. This ratio is more or less different for each of the barbiturates, and is caused by the different slopes of the absorbance difference curves between 240 and $260 \mathrm{~m} \mu$. From the determined absorption for each barbiturate, two parameters are composed that are placed as absis

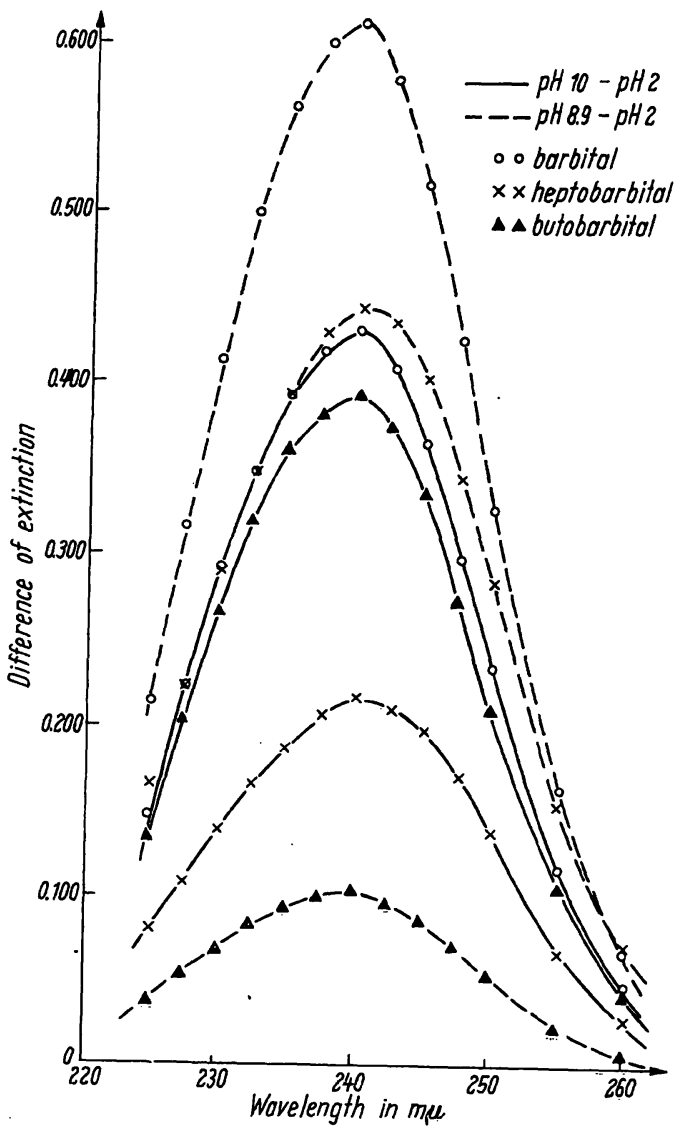

Fig. 1

Spectral absorption difference curves of barbiturates between aqueous solutions of $\mathrm{pH} 10$ and $\mathrm{pH} 2$ as well as those of $\mathrm{pH} 8.9$ and $\mathrm{pH} \mathrm{2,} \mathrm{obtained} \mathrm{from} \mathrm{sera} \mathrm{containing} 200 \mathrm{mg} / \mathrm{l}$ barbiturate

and ordinate in a graph. Parameter $I$, defined as the ratio at 240 and $250 \mathrm{~m} \mu$ of the absorption differences between pH 10 and $\mathrm{pH} 2$, is placed on the absis in a graph.

$$
\text { Parameter } \mathrm{I}=\frac{\mathrm{A}}{\mathrm{A} \frac{\mathrm{pH} 10-2}{240 \mathrm{~m} \mu}}
$$

On the ordinate of the graph is placed parameter II, which indicates the ratio of the absorption differences between solutions of $\mathrm{pH} 8.9$ and $\mathrm{pH} \mathrm{2}$, and those between solutions of $\mathrm{pH} 10$ and $\mathrm{pH} 2$ for $240 \mathrm{~m} \mu$.

$$
\text { Parạmeter II }=\frac{\mathrm{A}}{\mathrm{A}} \frac{\underset{240 \mathrm{~m} \mu}{\mathrm{pH} 10-2}}{240 \mathrm{~m} \mu .}
$$

In this way every barbiturate has its own place in the graph (fig. 2), although there is some overlapping. The quantitative determination of a barbiturate in serum is performed according to a reliable method reported by . VAN HAERINGen (2), using the linear relation between the measured absorption differences at $240 \mathrm{~m} \mu$ in the solutions of $\mathrm{pH} 10$ and $\mathrm{pH} 2$, and the barbiturate concentration in the serum. This relation is different for various barbiturates as shown in figures $3 \mathrm{a}$ and $3 \mathrm{~b}$. This method for quantitative determination and slight variations of it, have been described previously by Walker c.s. (6), Dybing (7) and Lous (8). 


\section{Identification and determination}

\section{Reagents}

Phosphate buffer pH 7.4: $0.908 \mathrm{~g} \mathrm{KH}_{2} \mathrm{PO}_{4}$ and $4.750 \mathrm{~g} \mathrm{Na}_{2} \mathrm{HPO}_{4}$. $2 \mathrm{H}_{2} \mathrm{O}$ are dissolved in $100 \mathrm{ml}$ distilled water.

Chloroform, redistilled, bp. 59-61.

$0.1 \mathrm{~N} \mathrm{NaOH}$ (A.R.).

Boric acid solution: $6.2 \mathrm{~g}$ boric acid (A.R.) in $1 / 0.1 \mathrm{~N} \mathrm{KCl}$. A mixture of equal volumes of this solution and $0.1 \mathrm{~N} \mathrm{NaOH}$ should form a buffer with $\mathrm{pH} 10 \cdot 0$ (test with indicator paper).

$4 \mathrm{~N} \mathrm{HCl}$.

Phosphate solution of $\mathrm{pH}$ 8.9: $8.90 \mathrm{~g} \mathrm{Na}_{2} \mathrm{HPO}_{4} \cdot 2 \mathrm{H}_{2} \mathrm{O}$ (A.R.) are dissolved in $250 \mathrm{~m} l$ distilled water.

\section{Procedure}

Extraction of sample with cbloroform

Add to a $100 \mathrm{~m} l$ scparating funnel, $1 \mathrm{~m} l$ serum, $0,4 \mathrm{~m} l$ phosphate buffer of $\mathrm{pH} 7.4$ and $55 \mathrm{ml}$ redistilled chloroform; shake for 5 minutes.

After separation, the chloroform solution is placed in a dry receiver, which is closed with a stopper and used for the extraction procedures at $\mathrm{pH} 8.9$ and $\mathrm{pH} 10$.

\section{Procedure at $\mathrm{pH} 8.9$}

$25 \mathrm{ml}$ of the chloroform solution, in a $100 \mathrm{~m} /$ separating funnel, are extracted with $6 \mathrm{ml}$ disodium hydrogen-ortho-phosphate solution ( $\mathrm{pH}$ 8.9) by shaking for 5 minutes. After separation, the chloroform layer is removed and the ortho-phosphate solution is centrifuged for 5 minutes at $3000 \mathrm{rpm}$.

The absorption of the clear solution is determined with a spectrophotometer in a quartz cuvette at $240 \mathrm{~m} \mu .6$ Drops of $4 \mathrm{~N} \mathrm{HCl}$ are then added to the solution in the cuvette so that the $\mathrm{pH}$ becomes 2 or less (test with indicator paper) and the absorption is determined again at $240 \mathrm{~m} \mu$. The absorption at $\mathrm{pH} 2$ is substracted from that at $\mathrm{pH} 8.9$.

\section{Procedure at $\mathrm{pH} 10$}

$25 \mathrm{ml}$ of the chloroform solution, in another $100 \mathrm{ml}$ separating funnel, are extracted with $6 \mathrm{ml}$ of $0.1 \mathrm{~N} \mathrm{NaOH}$ by shaking for 5 minutes. The chloroform layer is removed and the $\mathrm{NaOH}$ solution is centrifuged for 5 minutes at $3000 \mathrm{mpm} .3 .0 \mathrm{ml}$ of the clear solution are transferred to a test tube with a pipette and mixed with $3.0 \mathrm{ml}$ of boric acid solution. The mixture now has $\mathrm{pH} 10.0$. The absorption of this solution is determined with a spectrophotometer in quartz cuvettes at 230,240 and $250 \mathrm{~m} \mu$.

2 Drops of $4 \mathrm{~N} \mathrm{HCl}$ are then added to the solutions in the cuvettes. Now the $\mathrm{pH}$ is 2 or less (test with indicator paper). The absorption is determined again at 230,240 and $250 \mathrm{~m} \mu$. The values at $\mathrm{pH} 2$ are substracted from those at $\mathrm{pH}$ 10.0. A barbiturate is present, if the absorption differences show a maximum at $240 \mathrm{~m} \mu$ (see note 2).

\section{Notes}

If the absorption at $240 \mathrm{~m} \mu$ and $\mathrm{pH} 2$ for the "procedure at $p H 10$ " is higher than 0.150 and for the "procedure at $p H$ 8.9" is higher than 0.100 , an interfering substance may be present. The chloroform solution should then be washed twice with $1 \mathrm{ml}$ of $30 \%$ $\mathrm{H}_{2} \mathrm{SO}_{4}$, once with $1 \mathrm{~m} l$ of water and finally once with $0.5 \mathrm{ml}$ of phosphate buffer, $\mathrm{pH}$ 7.4.

For prominal the maximum is found at $250 \mathrm{~m} \mu$; hovever the absorption difference at $240 \mathrm{~m} \mu$ is definitely greater than that at $230 \mathrm{~m} \mu$.

\section{Identification}

The substance is plotted in the barbiturate diagram (fig. 2) by glacing the value of parameter I on the absis and that of parameter II on the ordinate. The determined position indicates the identity of the barbiturate present.

\section{Determination of the concentration in the serum}

The barbiturate concentration is determined from the absorption differences between $\mathrm{pH} 10$ and $\mathrm{pH} 2$ at $240 \mathrm{~m} \mu$, by comparison with those of a calibration curve for barbital (fig. 3). The determined concentration is multiplied by the appropiate barbiturate factor.

\section{Example}

Identification and determination of serum samples $A$ and $B$, containing $100 \mathrm{mg} / \mathrm{l}$ each of phenobarbital and allobarbital, respectively.

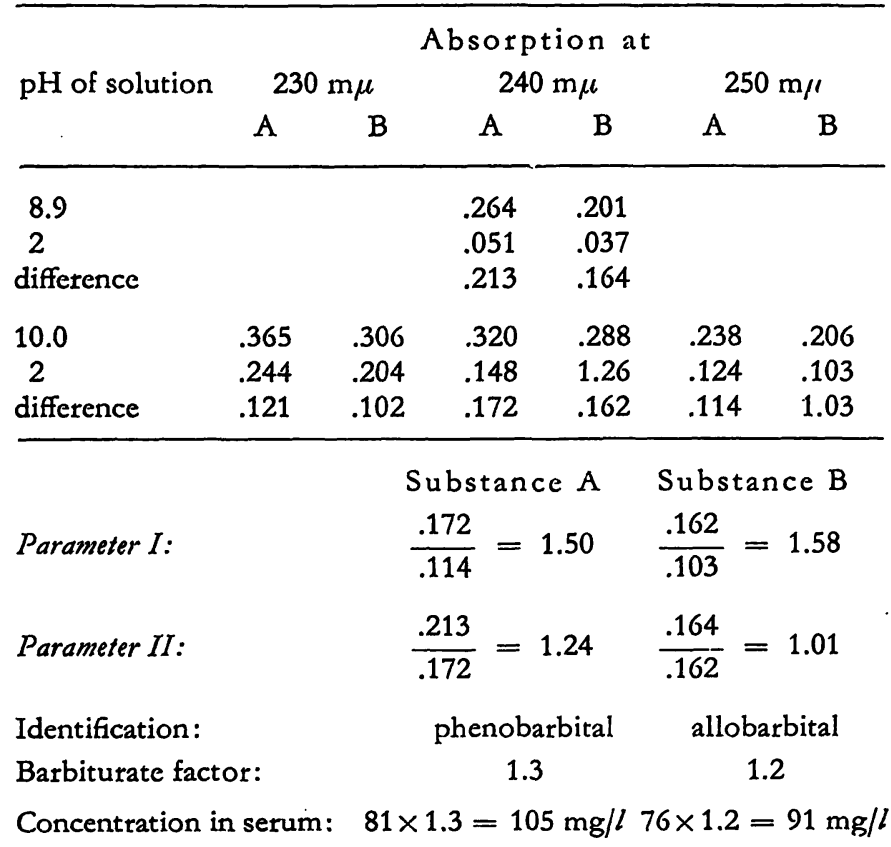

\section{Discussion and Results}

\section{Identification}

To identify a barbiturate in a case of poisoning we direct ourselves in first place to those substances that are used in a definite country or region and especially to those, that are easily available to the public. Table 1 shows a survey of the values of parameters I and II composed from ten determinations for each of the various barbiturates.

Figure 2 shows the places of the substances mentioned in table 1 , in a barbiturate graph. The places are obtained by placing in the graph for each of the barbiturates the mean values of parameters I and II plus or minus twice their standard deviations. This means that $95 \%$ of all possible plots for a barbiturate in the diagram are covered by the areas of the indicated place.

The song-acting barbital, phenobarbital and heptobarbital are found in the higher part of the diagram. Methylphenobarbital, a N-methyl barbital, which is also a long-acting barbiturate, however is found in the lower part of the diagram. Of the examined barbiturates, heptobarbital (rutonal), methyl phenobarbital (prominal), hexabarbital (evipan), barbital (veronal), phenobarbital (luminal) and allobarbital can be identified. Butobarbital (soneryl), heptabarbital (medomin) and pentobarbital (nembutal) cannot be distinguished from each other.

\section{Evaluation of concentration}

For various barbiturates, the absorption differences at $240 \mathrm{~m} \mu$ between solutions of $\mathrm{pH} 10$ and $\mathrm{pH} 2$, are different for equal weight concentrations as shown in table 2 . 
Tab. 1

Parameters I, II and barbiturate factors for several barbiturates

\begin{tabular}{|c|c|c|c|c|c|c|c|}
\hline \multirow[t]{2}{*}{ Barbiturate } & & \multirow{2}{*}{$\begin{array}{l}\text { Mol. } \\
\text { weight }\end{array}$} & \multicolumn{2}{|c|}{ Parameter I } & \multicolumn{2}{|c|}{ Parameter II } & \multirow{2}{*}{$\begin{array}{l}\text { Barbiturate } \\
\text { factor }\end{array}$} \\
\hline & & & Mean* & Stand. dev.* & Mean* & Stand. dev.* & \\
\hline \multicolumn{2}{|c|}{ Methylphenobarbital (prominal) } & 246 & 0.91 & 0.047 & 0.17 & 0.120 & 2.1 \\
\hline Hexabarbital & (evipan) & 234 & 1.11 & 0.049 & 0.12 & 0.065 & 1.8 \\
\hline Pentobarbital- $\mathrm{Na}$ & (nembutal) & 248 & 1.70 & 0.050 & 0.20 & 0.090 & 1.3 \\
\hline Heptabarbital & (medomin) & 250 & 1.80 & 0.067 & 0.28 & 0.060 & 1.3 \\
\hline Butobarbital & (soneryl) & 212 & 1.86 & 0.080 & 0.30 & 0.045 & 1.0 \\
\hline Cyclobarbital-Ca & (phanodorm) & 275 & 1.62 & 0.062 & 0.44 & 0.048 & 1.1 \\
\hline Aprobarbital & & 210 & 1.53 & 0.034 & 0.56 & 0.055 & 1.2 \\
\hline Allobarbital & (dial) & 208 & 1.53 & 0.048 & 0.96 & 0.058 & 1.2 \\
\hline Phenobarbital & (luminal) & 232 & 1.52 & $0: 070$ & 1.15 & 0.060 & 1.3 \\
\hline Barbital & (veronal) & 184 & 1.86 & 0.113 & 1.36 & 0.083 & 1.0 \\
\hline Heptobarbital & (rutonal) & 218 & 1.52 & 0.042 & 1.90 & 0.180 & 1.8 \\
\hline
\end{tabular}

* Calculated from 10 determinations for each of the barbiturates

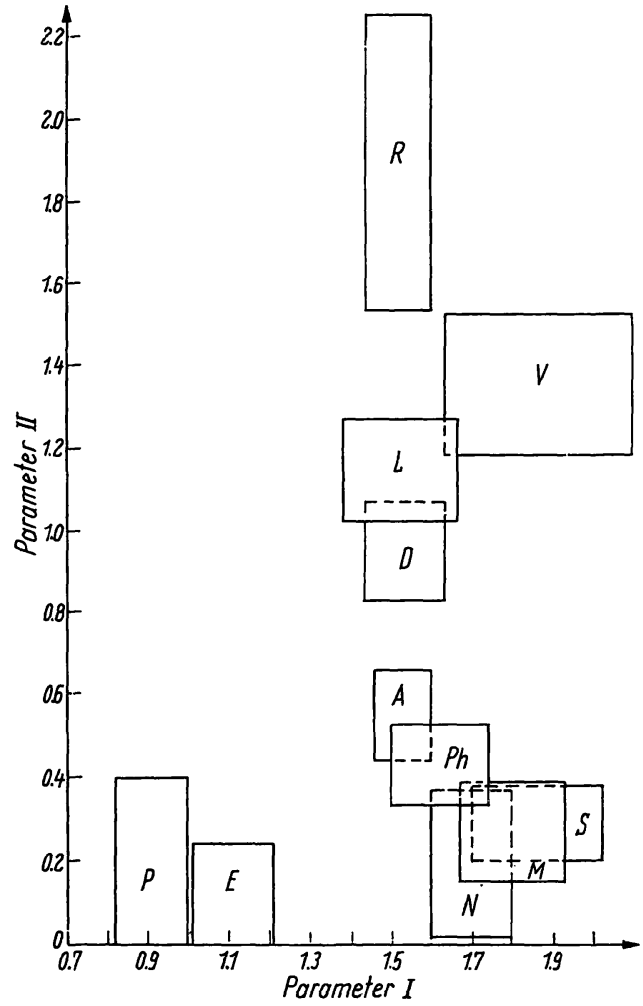

Fig. 2

Barbiturate diagram.

Places of barbiturate expressed in parameters I and II

$\begin{array}{llll}P & =\text { methyl phenobarbital (prominal) } & A=\text { aprobarbital } & \\ E=\text { hexabarbital } & \text { (evipan) } & D=\text { allobarbital } & \text { (dial) } \\ N=\text { pentobarbital } & \text { (nembutal) } & \mathrm{L}=\text { phenobarbital } & \text { (luminal) } \\ \mathrm{N}=\text { heptabarbital } & \text { (medomin) } & \mathrm{V}=\text { barbital } & \text { (veronal) } \\ \mathrm{S}=\text { butobarbital } & \text { (soneryl) } & \mathrm{R}=\text { heptobarbital } & \text { (rutonal) }\end{array}$

Figures $3 \mathrm{a}$ and $3 \mathrm{~b}$ show the graphical representation of the data mentioned in table 2 .

It is evident that for the determination of the barbiturate concentration in serum we have to use the corresponding calibration line for the barbiturate that is present. In practice it will be more convenient to use only the calibration curve for barbital and to multiply the determined concentration with a factor corresponding to the barbiturate that is present. This barbiturate factor indicates the weight concentration ratio for equal absorbances between a barbiturate and barbital.
A survey of the barbiturate factors for several generally known barbiturate obtained from figure $3 \mathrm{a}, \mathrm{b}$ is given in table 1 . The barbiturate factors correspond rather well with the molar ratios of the barbiturates with respect to barbital, except methyl phenobarbital, hexabarbital, heptobarbital and cyclobarbital.

The mean absorption difference for 18 sera without barbiturate was 0.017 . In figures $3 \mathrm{a}$ and $3 \mathrm{~b}$ all curves are

Tab. 2

Absorption differences at $240 \mathrm{~m} \mu$ between $\mathrm{pH} 10$ and $\mathrm{pH} 2$ for various barbiturates at several serum* concentrations ${ }^{1}$ )

\begin{tabular}{|c|c|c|c|c|c|c|}
\hline \multirow[t]{2}{*}{ Barbiturate } & \multicolumn{6}{|c|}{$\begin{array}{l}\text { Absorption differences at } 240 \mathrm{~m} \mu \text { obtained } \\
\text { for a barbiturate concentration in serum of } \\
\qquad \mathrm{mg} / \mathrm{l} \text { : }\end{array}$} \\
\hline & 50 & 67 & 100 & 133 & 150 & 160 \\
\hline Barbital & & $\begin{array}{l}147 \\
143\end{array}$ & $\begin{array}{l}216 \\
202\end{array}$ & $\begin{array}{l}273 \\
274\end{array}$ & 310 & 325 \\
\hline Butobarbital & & 154 & $\begin{array}{l}208 \\
188 \\
214\end{array}$ & 266 & 302 & \\
\hline Cyclobarbital & & 137 & $\begin{array}{l}193 \\
169 \\
197\end{array}$ & $\begin{array}{l}240 \\
254\end{array}$ & 268 & 289 \\
\hline Allobarbital & & $\begin{array}{l}126 \\
130\end{array}$ & $\begin{array}{l}177 \\
190\end{array}$ & 237 & $\begin{array}{l}273 \\
263\end{array}$ & \\
\hline Aprobarbital & & 130 & $\begin{array}{l}191 \\
173\end{array}$ & $\begin{array}{l}241 \\
236 \\
245\end{array}$ & 260 & \\
\hline Pentobarbital & & 132 & $\begin{array}{l}169 \\
165\end{array}$ & 195 & 236 & 274 \\
\hline Heptabarbital & & $\begin{array}{l}111 \\
115\end{array}$ & $\begin{array}{l}165 \\
183\end{array}$ & 215 & & 245 \\
\hline Phenobarbital & & $\begin{array}{l}108 \\
109\end{array}$ & $\begin{array}{l}135 \\
159\end{array}$ & 205 & $\begin{array}{l}244 \\
254\end{array}$ & \\
\hline Heptobarbital & & 80 & $\begin{array}{l}137 \\
115\end{array}$ & 152 & 191 & \\
\hline Hexabarbital & 50 & $\begin{array}{l}75 \\
84\end{array}$ & 121 & 165 & & \\
\hline Methylphenobarbital & & 78 & $\begin{array}{l}107 \\
110\end{array}$ & 137 & & \\
\hline
\end{tabular}

*) $1,1 \mathrm{ml}$ Serum used in procedure.

1) The barbiturate concentrations are obtained by mixing serum in different rations with barbiturate solutions containing $200 \mathrm{mg} / \mathrm{l}$. The latter are obtained by dissolving $40 \mathrm{mg}$
barbiturate in $4.0 \mathrm{ml}$ of $0.1 \mathrm{~N} \mathrm{NaOH}$ and mixing $0.2 \mathrm{~m} /$ of this solution with $10 \mathrm{ml}$ serum. 


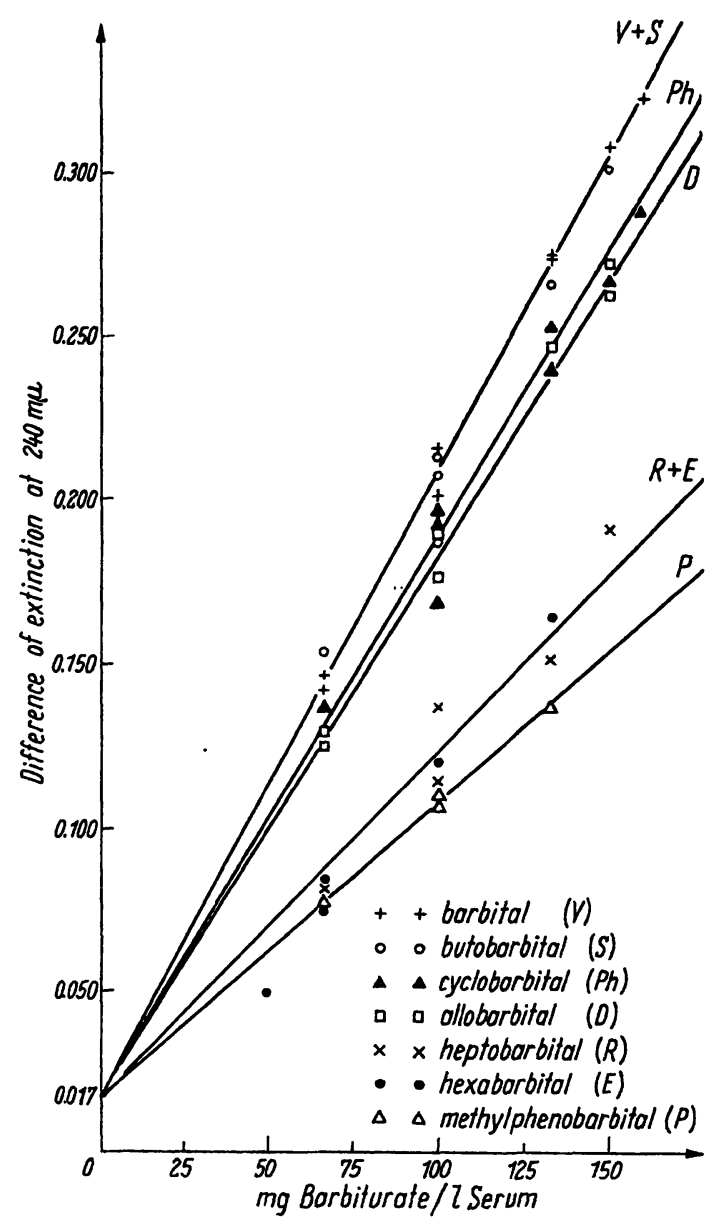

Fig. $3 a$

Absorption difference curves of barbiturates at $240 \mathrm{~m} \mu$ between aqueous solutions of $\mathrm{pH} 10$ and $\mathrm{pH} 2$, obtained from sera containing various barbiturates of different concentrations

drawn through this point. The standard deviation of these blank values was 0.010 . From figure 3 it is shown that on this basis the accuracy of the determination is not better than $\pm 10 \mathrm{mg} / \mathrm{l}$ serum for barbital. Low barbiturate concentrations therefore cannot be determined by this method. Since comatosis begins to appear at an "intermediate-acting" barbiturate concentration of 60 till $70 \mathrm{mg} / \mathrm{l}$ serum, the method is suitable for use in a moderate or severe case of barbiturate poisoning. Especially when the kind of barbiturate can be identified, the intoxication can be confirmed with a high degree of certainty, because it is unlikely that an interfering substance has the same parameters as a barbiturate. Acetylacetic acid also shows absorption in the barbiturate region, although there is no maximum at $240 \mathrm{~m} \mu$. How-

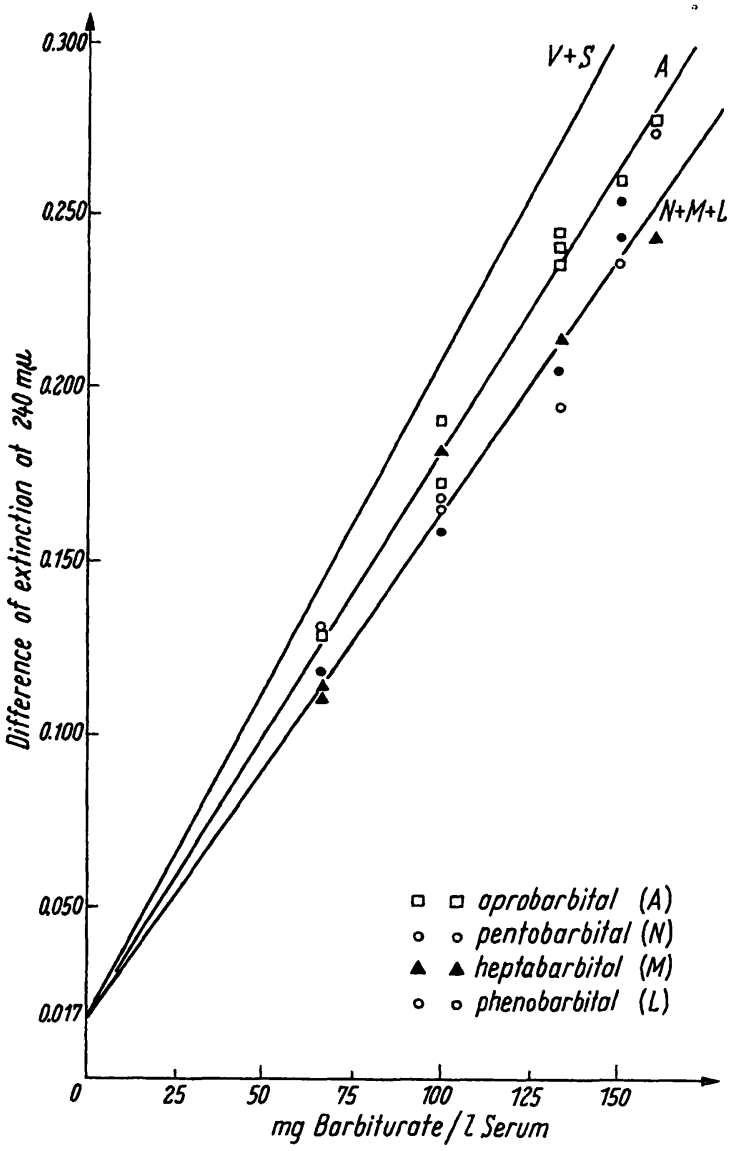

Fig. $3 b$

Absorption difference curves of barbiturates at $240 \mathrm{~m} \mu$ between aqueous solutions of $\mathrm{pH} 10$ and $\mathrm{pH} 2$, obtained from sera containing various barbiturates of different concentrations

ever, in sera from diabetic patients the absorption of this substance does not seriously disturb the barbiturate identification and determination.

\section{Conclusion}

The identification of barbiturates at relative high concentrations in serum can be performed spectrophotometrically. Of various known barbiturates, the greater part can be identified with certainty, leaving two or three possible substances. A case barbiturate poisoning can be established with a high degree of certainty and its quantitative determination can be performed with more precision if the barbiturate present in serum is known. My thanks are due to Drs. H. J. Pexters of St. Canisius Hospital and Drs. P. J. J. van Munster of the Pediatric Clinic of the University of Nijmegen, for their interest and belpfull criticism.

\section{References}

1. Sunshine, I., Standard Methods of Clinical Chemistry - Batbiturate - Vol. 3, p. 46. Academic Press, New York (1961). - 2. Stevenson, G. W., Analytic. Chem. 33, 1374 (1961); 33, 1903 (1961). - 3. van Haeringen, A., Pharmac. Weekbl. 97,173 (1962). - 4. Goldbaùm, L. R., Analytic. Chem. 24, 1604 (1952). - 5.
Heltoporfr, I., Scand, J. Clin. Laborat. Invest. 7, suppl. 20, 127 (1955). - 6. WALKER, J. T., R. S. FISCHER and J. J. MC Hugh, Ámer. J. Clin. Path. 18, 451 (1948). - 7. Drbing, F., Scand. J. Clin. Laborat. Invest 7, suppl. 20, 114 (1955). - 8. Lous, P., Acta pharmacol. toxicol. (Köbenhavn) 6, 227 (1950). 